\title{
Variation in particulate PAHs levels and their relation with the transboundary movement of the air masses
}

\author{
Khaiwal Ravindra $^{\mathrm{a}, \mathrm{b}, *}$, Eric Wauters ${ }^{\mathrm{c}}$ and René Van Grieken ${ }^{\mathrm{b}}$ \\ ${ }^{a}$ Centre for Atmospheric and Instrumentation Research (CAIR), University of \\ Hertfordshire, Hatfield, AL10 9AB, United Kingdom \\ ${ }^{\mathrm{b}}$ Environmental Analysis Group, Department of Chemistry, University of Antwerp, \\ Universiteitsplein 1, B-2610 Antwerp, Belgium \\ 'Flemish Environment Agency (VMM), Krijgslaan 281, S2, B-9000 Gent, Belgium
}

\section{Abstract}

The levels of particulate polycyclic aromatic hydrocarbons (PAHs) were determined with a fast analytical approach to study their seasonal variations at Menen (Belgium) during 2003; they were noticed to be 5-7 times higher in January, February and December, in comparison to May, June and August. The annual average concentration of sum of 16 US Environmental Protection Agency (EPA) criteria PAHs was $6.7 \mathrm{ng} / \mathrm{m}^{3}$ and around $63 \%$ of it was found to be probably carcinogenic to humans. The application of diagnostic ratio and principal component analysis showed vehicular emission as a major source. An increased ratio of 'combustion PAHs' to 'total EPA-PAHs' during the winter season indicated towards combustion activities. Further, the differences in PAHs concentration were assessed with relation to backward air mass trajectories, which show that the levels of PAHs increases when there is an air mass movement from Central and Western Europe and a fall when the trajectories spend most of their 4-days time over the Atlantic Ocean or in the Arctic region.

Keywords: PAHs; Pressurized liquid extraction; nonalkylated PAHs; combustion emission; air mass backward trajectories and long range transport.

* Corresponding author, Khaiwal Ravindra, Khaiwal@ yahoo.com , +44(0) 1707 285232; +44(0) 1707284208 


\section{Introduction}

The polycyclic aromatic hydrocarbons (PAHs) are of major health concern, mainly

3 due to their well-known carcinogenic and mutagenic properties. PAHs and their metabolites

4 can form DNA adducts, which can induce mutation (Lewtas, 1993, 2007; Ravindra et al.,

5 2001; Binkova et al., 1999, 2003; Sram et al., 2007a,b). These adverse properties demands

6 to assess their concentration, trends and source profile in the atmosphere to provide an aid

7 to manage regional as well as global air pollution control strategies (Ravindra et al., 2001, 8 2008; Breivik et al., 2006). Atmospheric PAHs are partitioned between the particulate and

9 the gaseous phases. However, the carcinogenic 5- and 6- ring species are predominantly 10 associated with particles, especially those falling in the accumulation mode $(0.5 \mu \mathrm{m}<d<1$

$11 \mu \mathrm{m}$ ) that deposit only slowly from the atmosphere and, depending on atmospheric

12 conditions, may be airborne for days and be transported over long distances (Venkataraman

13 et al., 1994; Manoli et al., 2004; Mantis et al., 2005). Ravindra et al. (2006a) studied PAH

14 levels at various sites in Belgium and found that vapor phase PAHs represent more site 15 specific characteristics than aerosol phase PAHs. However, the variations in aerosol phase 16 (particle/droplet associated) PAHs levels also show their relation with local as well as the 17 regional anthropogenic activities.

18 The occurrence of specific PAH compounds, or a group of PAHs, has been used to 19 indicate the corresponding emission sources (Ravindra et al., 2008). Additionally, as PAHs 20 associated with airborne particles vary significantly as a function of their emission sources,

21 some PAH concentration ratios have been used to indicate vehicular emission sources 22 (Rogge et al., 1993; Venkataraman et al., 1994; Khalili et al., 1995). In most of the studies, 23 principal component analysis (PCA) was used to enhance the accuracy of emission source 
1 identification (Ho et al., 2002; Park et al., 2002; Fang et al., 2004; Ravindra et al., 2006a, 2 b).

Air mass backward trajectories provide a useful means of establishing source-

4 receptor relationships of air pollutants (Stohl, 1998; Beverland et al., 2000). Pollutants

5 emitted from various sources, can remain in the atmosphere sufficiently long to be

6 transported thousands of kilometres and thus to spread over a large area, across national

7 borders, far from the original sources of polluting emission. There are many studies, which

8 confirm that the general atmospheric circulation leads to long-range transport of aerosol or

9 suspended particulate matter (SPM) over various regions of the world (Buchanan et al.,

10 2002; Graham et al., 2004; Grennfelt and Hov, 2005). These aerosols carry a complex

11 mixture of various inorganic and organic species including PAHs, originating from

12 different sources. As mentioned above, a number of studies investigate the origin and

13 transboundary movement of inorganic constituents of aerosol but little attention has been

14 given for organic constituents and specifically for PAHs.

15 In the present study, the concentrations of 16 US Environmental Protection Agency

16 (EPA) priority listed particulate PAHs were assessed during different seasonal conditions at

17 Menen, Belgium. Menen was selected considering its background nature and closeness to

18 the French border. This site can reflect the influence of industrial activities and long range

19 transport on particulate PAHs levels. Various multivariate techniques such as correlations,

20 diagnostic ratio and PCA were applied to characterize and identify the possible dominant

21 emission sources of PAHs. Furthermore the variations in PAHs levels were evaluated with

22 relation to various emission sources and backward air mass trajectories to study the

23 regional / global impact. The understanding of organic pollutants behavior across national

24 borders provides an aid to manage regional/ global air pollution control strategies. 


\section{Experimental}

\section{Site selection}

3 The emphasis of the study lies on the border area between Belgium and France to

4 study the regional-global impact on PAHs levels. The selected sampling site was located at

5 the Wervikstraat at the outskirts of the town of Menen and near the border of France

6 (supplementary Figure S1). The sampling site at Menen may be influenced by emissions

7 from the industrial activities in the conurbations Lille and Dunkerque in France. The town

8 covers an area of $33.1 \mathrm{~km}^{2}$ and has a population of 32,000 inhabitants. The sampling site is

9 located in an open environment, in order to permit a good circulation of the air and is $8 \mathrm{~km}$

10 from the French city Tourcoing, in a northerly direction. The region between Tourcoing

11 and Halluin can be classified as a suburban zone; the areas around Wervicq and Rollegem

12 have a more rural character.

\section{Sampling}

14 Total suspended particulate samples $(n=63)$ were collected on quartz fiber filters

15 (Ø 150mm) for the determination of EPA-PAHs using a Digitel High Volume sampler

16 DHA-80 (DIGITEL Elektronik AG, Switzerland). The average flow rate was 350 1/min

17 with an approximate sampling time of 48 h. DHA-80 has a container of 15 filters stretched

18 in filter holders and they are changed automatically to the flow position at the pre-set time.

19 After the sampling, the filters were wrapped in aluminum foil separately and stored in a

20 freezer at $-20{ }^{\circ} \mathrm{C}$, until they were extracted. During each month of 2003,5 to 9 samples

21 were collected except in July, when no sampling was possible due to instrument problems.

22 Wind-speed (WS), wind direction (WD), relative humidity (RH), air temperature (Tair), air 
1 pressure (pair), and precipitation (PR) were recorded at meteorological stations of the

2 Flemish Environmental Agency (VMM) nearby the sampling sites.

\section{Fast analytical approach}

4 The samples were extracted using pressurized liquid extraction (PLE) or 5 Accelerated Solvent Extraction (Dionex, Titan Way, CA, USA), which offers a very fast

6 extraction of PAHs i.e. in 30 minutes; with equal or even better efficiency than Soxhlet

7 extraction and minimum consumption of the toxic solvents (Godoi et al., 2004; Ravindra et

8 al., 2006a, b). The filters were loaded in the $34 \mathrm{ml}$ extraction cell. The extractions were

9 performed using a pressure of $10 \mathrm{MPa}$ at an oven temperature of $100{ }^{\circ} \mathrm{C}$. A solvent

10 combination of 1:1 dichloromethane/acetone was used for extraction. The flush volume was

$1160 \%$ of the volume of the extraction cell. The full cycle was repeated four times, and after

12 the extraction, the instrument was purged at $1 \mathrm{MPa}$ for $60 \mathrm{~s}$ with nitrogen. Pre-rinsed $60 \mathrm{ml}$

13 screw cap I- Chem Vials were used to collect the extracts. Finally, the extracts were

14 enriched in a Turbo Vap 500 (Zymark, Hopkinton, MA, USA) concentration workstation

15 and recovered in $1 \mathrm{ml}$ of acetonitrile. Blank filters were also extracted using the same

16 procedure as the one mentioned above.

\section{Analytical procedure}

18 The extracts were analyzed by high performance liquid chromatography (HPLC;

19 Waters, Milford, MA, USA) with programmed fluorescence detection (Perkin-Elmer

20 LC240, Norwalk, CT, USA). Separation of the PAHs was accomplished using a Vydac

$21201 \mathrm{TP}(250 \mathrm{~mm} \times 4.6 \mathrm{~mm})$ column, with a gradient elution ranging from a $50+50 \%$

22 acetonitrile-water mixture to $100 \%$ acetonitrile in $20 \mathrm{~min}$. The fluorescence of PAH was

23 monitored with an automatic adjustment of the wavelengths for each compound according

24 to the retention time. The excitation wavelengths ranged between 260 and $300 \mathrm{~nm}$, while 
1 the emission wavelengths lay between 380 and $465 \mathrm{~nm}$. Linear calibration graphs were

2 obtained for every compound in the concentration ranges up to $800 \mathrm{ng} / \mathrm{ml}$. The detected and

3 quantified PAHs were: naphthalene (Nap), acenapthylene (AcPy), acenaphthene (Acp),

4 fluorene (Flu), anthracene (Ant), phenanthrene (PA), fluoranthene (Flut), pyrene (Pyr),

5 benzo[a]anthracene $(\mathrm{B}[\mathrm{a}] \mathrm{A}), \quad$ chrysene $\quad(\mathrm{Chr})$, benzo[b]fluoranthene $(\mathrm{B}[\mathrm{b}] \mathrm{F})$,

6 benzo[k]fluoranthene $(\mathrm{B}[\mathrm{k}] \mathrm{F})$, benzo[a]pyrene $(\mathrm{B}[\mathrm{a}] \mathrm{P})$, dibenzo[a,h]anthracene $(\mathrm{D}[\mathrm{ah}] \mathrm{A})$,

7 benzo[g,h,i]perylene (B[ghi]P) and indeno[1,2,3-c,d]pyrene (Ind). The limit of quantitation

8 varied from 0.001 to $0.014 \mathrm{ng} / \mathrm{m}^{3}$ for various PAHs (see supplementary Table S1). As no

9 gas phase back up filters were used during sampling, the concentrations of the most volatile

10 compounds (the first 6 in the above list) do not reflect the real concentrations in air but

11 report the amounts which remained sorbed/condensed on the particles collected on the

12 quartz fibre filter.

13 Quality assurance

14 All analytical data were subjected to strict quality control. Blank and spiked 15 samples were analyzed with each set of samples. The extraction recovery efficiencies were 16 determined using a certified / standard reference material (SRM) of the National Institute of 17 Standards and Technology (NIST): SRM1650a (Diesel Particulate Matter) and they were 18 better than $80 \%$. The NIST standard PAH (SRM 1647d) mixture (Schmidt, Amsterdam, 19 The Netherlands) was used for calibration of the analytical method and the NIST SRM 202260 was also used for the spiking of the test sample for the routine quality control. The 21 standardized test method for PAHs was accredited by Beltest (http://belac.ggov.be) under 22 the number 163- Test (norm ISO- 17025). 


\section{Results and discussion}

\section{Potential carcinogenic fraction of particulate PAHs}

3 In the environment, individuals are most likely to be exposed to PAHs vapors or

4 PAHs that are attached to dust or other particles in the air (Lewtas, 2007). Exposure to

5 PAHs and SPM can results in cell mutation (Ravindra et al., 2001; Binkova et al., 2003;

6 Sram et al., 2007a,b). The results of an experimental animal study on inhaled diesel soot-

7 adsorbed $\mathrm{B}[\mathrm{a}] \mathrm{P}$, a marker $\mathrm{PAH}$, indicate that direct absorption through the alveolar

8 epithelium is an important route of entry of unmetabolized PAHs (Gerde et al., 2001).

9 The carcinogenicity classifications verified by EPA Carcinogenicity Risk

10 Assessment Endeavor Work Group (EPA, 1994) shows that B[a]A, B[b]F, B[k]F, B[a]P,

$11 \mathrm{Chr}, \mathrm{D}[\mathrm{ah}] \mathrm{A}$ and Ind are considered to be probable human carcinogens, whereas other

12 PAHs such as AcPy, Ant, B[ghi]P, Flut, fluorene, PA and Pyr are not classified as

13 promoters of the same health risk. According to a public health statement

14 (http://www.atsdr.cdc.gov/toxprofiles/phs69.html) by Agency for Toxic Substances and

15 Disease Registry (ATSDR), the International Agency for Research on Cancer (IARC) has

16 determined that $\mathrm{B}[\mathrm{a}] \mathrm{A}$ and $\mathrm{B}[\mathrm{a}] \mathrm{P}$ are probably carcinogenic to humans; $\mathrm{B}[\mathrm{b}] \mathrm{F}$,

17 benzo[j]fluoranthene $(\mathrm{B}[\mathrm{j}] \mathrm{F}), \mathrm{B}[\mathrm{k}] \mathrm{F}$, and Ind are possibly carcinogenic to humans; whereas

18 Ant, B[g,h,i]P, benzo[e]pyrene (B[e]P), Chr, Flut, Flu, PA, and Pyr are not classifiable as to

19 their carcinogenicity to humans. The Department of Health and Human Services (DHHS)

20 has determined that $\mathrm{B}[\mathrm{a}] \mathrm{A}, \mathrm{B}[\mathrm{b}] \mathrm{F}, \mathrm{B}[\mathrm{j}] \mathrm{F}, \mathrm{B}[\mathrm{k}] \mathrm{F}, \mathrm{B}[\mathrm{a}] \mathrm{P}, \mathrm{D}[\mathrm{a}, \mathrm{h}] \mathrm{A}$, and Ind are known animal

21 carcinogens. Acp has not been classified for carcinogenic effects by the DHHS, IARC, or

22 EPA The potential carcinogenic fraction of PAHs, calculated based on the EPA (1994)

23 criteria shows that around $63 \%$ of total particulate EPA-PAHs fraction determined in this 
1 study is probably carcinogenic to human. During various months the carcinogenic fraction

2 of PAHs varies from 44\% (August) to 70\% (November; December). Further estimation

3 shows that the percentage of carcinogenic fraction of PAHs becomes higher with the

4 increase in total ambient levels of EPA-PAHs and has maximum values in winter.

The World Health Organization (WHO, 2000) suggests that the unit risk of lung

6 cancer is $87 \times 10^{-6}$ per $n g \mathrm{~B}[\mathrm{a}] \mathrm{P}$ per $\mathrm{m}^{3}$ for a life time exposure. Considering the upper limit

7 of the additional lifetime risk should be less than $1 \times 10^{-4}$ and health based evidence, a non-

8 mandatory target value of $1.0 \mathrm{ng} / \mathrm{m}^{3}$ (yearly) is proposed for $\mathrm{B}[\mathrm{a}] \mathrm{P}$ in fourth daughter

9 directive of European Union (PAHs position paper, 2001). Compared to this, the annual

10 average value of $\mathrm{B}[\mathrm{a}] \mathrm{P}$ is somewhat lower, i.e. $0.6 \mathrm{ng} / \mathrm{m}^{3}$, in Menen. Further the monthly

11 average value exceeds this target value during December, January and February. This

12 seasonal increase in PAHs levels may raise the concern as the direct effect of PAHs and

13 other mutagens were considered to be a maximum of five lung cancer cases each year per

14 one million individuals (Nielsen et al., 1996). Occupational exposures to PAHs are strongly

15 suspected to increase lung cancer risk (Bruske-Hohlfeld et al., 2000).

16 Temporal pattern of PAHs

17 Sixteen US EPA criteria PAHs were determined at Menen because they are

18 suspected to be more harmful than some of the others and exhibit adverse effects that are

19 representative of the PAHs (ATSDR, 1995). Table 1 gives an overview of the temporal

20 distribution of these PAHs concentration in aerosol samples during 2003 at Menen. PAHs

21 have low vapor pressure and hence some PAHs are present at ambient temperature in air,

22 both as gases and associated with particles. Although the lighter PAHs, such as PA, are

23 found almost exclusively in gas phase, the heavier PAHs, such as $\mathrm{B}[\mathrm{a}] \mathrm{P}$, are almost totally

24 sorbed onto particles (Manahan, 1994). This is also evident from Table 1, which 
1 demonstrates that the concentrations of lower molecular weight PAHs $(<200)$ were found

2 relatively very low in filter samples in comparison to high molecular weight PAHs

3 fractions at Menen. Further only Nap $\left(0.15 \mathrm{ng} / \mathrm{m}^{3}\right)$ and PA $\left(0.19 \mathrm{ng} / \mathrm{m}^{3}\right)$ concentration were

4 found noticeable in lighter molecular weight fraction of PAHs, whereas the high molecular

5 weight species like, Flut $\left(0.83 \mathrm{ng} / \mathrm{m}^{3}\right), \mathrm{Chr}\left(0.87 \mathrm{ng} / \mathrm{m}^{3}\right), \mathrm{B}[\mathrm{b}] \mathrm{F}\left(0.84 \mathrm{ng} / \mathrm{m}^{3}\right), \mathrm{B}[\mathrm{a}] \mathrm{P}(0.58$

$\left.6 \mathrm{ng} / \mathrm{m}^{3}\right)$, B [ghi]P $\left(0.73 \mathrm{ng} / \mathrm{m}^{3}\right)$ and Ind $\left(0.77 \mathrm{ng} / \mathrm{m}^{3}\right)$, dominate the PAHs fraction of filter

7 samples. The data also reveals that the daily PAHs concentration were also influenced by

8 the prevailing wind directions during sampling days and the concentration was relatively

9 high when the prevailing wind directions were SW at the sampling site (please see 10 supplementary Table 1a,b,c).

\section{Seasonal variation in PAHs levels}

12 Table 1 shows the monthly average concentration of individual PAHs at Menen,

13 while Figure 1 shows the monthly average concentration of PAHs. It is evident from Figure

141 , that the PAHs concentrations were significantly higher during winter season in

15 comparison to summer at Menen, the annual average concentration of PAHs being 6.7

$16 \mathrm{ng} / \mathrm{m}^{3}$. The monthly average PAHs concentrations were 5-7 times higher in January,

17 February and December, in comparison to May, June and August. In contrast to Binkova et

18 al. (2003), Manoli et al. (2004) and Sklorz et al., (2007); the present study shows higher

19 levels of B[ghi]P during winter and likely suggest towards local/regional emission sources.

20 However, following the trend of Sklorz et al. (2007); this study also obtained higher levels

21 of B[a]A, B[b]F, B[k]F, and Ind during winter. Binkova et al. (2003) also reported 4-6 fold

22 higher levels of $\mathrm{B}[\mathrm{a}] \mathrm{P}$ and $\mathrm{Chr}$ during winter than summer and they identified residential

23 heating as an additional main emission source during winter. Similarly Lee et al. (2005)

24 also suggested that additional emission of pollutants can be expected during winter from 
1 various sources such as domestic heating, power plants etc. Further, the mixing height of

2 pollutants also reduces with a fall in temperature and restricts the mixing of pollutants in

3 the atmosphere.

4 The other possible reason of high concentration of PAHs during winter season 5 seems to be related with the very low temperature during these periods, which made

6 favorable conditions for the condensation/sorption of these species on suspended particles

7 in air. However, condensation/sorption mainly influence PAH having a significant

8 concentration in gas phase, not the PAH with 5 aromatic rings. Normally PAHs with 5 or

9 more aromatic rings are found almost associated (more than 95\%) with aerosol even at

$1025^{\circ} \mathrm{C}$. Interestingly, these PAHs also show some variation between summer and winter and

11 hence can be used for source apportionment (Sklorz et al., 2007).

\section{Source apportionment}

\section{Correlations and diagnostic ratio}

14 The correlation of the PAHs data obtained from Menen was evaluated by regression 15 analysis and their correlation coefficients, which show that $\mathrm{Chr}, \mathrm{B}[\mathrm{b}] \mathrm{F}, \mathrm{B}[\mathrm{k}] \mathrm{F}, \mathrm{B}[\mathrm{a}] \mathrm{P}$, $16 \mathrm{D}[\mathrm{ah}] \mathrm{A}, \mathrm{B}[\mathrm{ghi}] \mathrm{P}$ and Ind, have a very strong correlation among them $\left(\mathrm{R}^{2} \geq 0.8 ; \mathrm{p}<0.01\right)$

17 and hence one of these PAHs can be used as an indication of other PAHs. Further this 18 likely indicates towards a similar emission source of PAHs. There was no strong 19 correlation found between low molecular weight PAHs and high molecular weight PAHs 20 species. Previous studies also show that the concentrations of particulate sampled PAHs 21 with equal or less than 4 aromatic rings are strongly influenced by the ambient temperature 22 during sampling and mainly found in vapor phase (Yamasaki et al., 1982; Ligocki and 23 Pankow, 1989). 
The diversity in PAHs sources could also be characterized from diagnostic ratios.

2 The concentration of specific PAH compounds, or a group of PAHs, have been used to

3 identify the emission sources. In recent years many studies have used the diagnostic ratio

4 and the following conclusions can be drawn from them. Grimmer et al. (1983) reported Ind/

5 (Ind+B[ghi]P) values of $0.18,0.37,0.56$ and 0.62 , for gasoline, diesel, coal, and wood

6 burning respectively. However other studies used a ratio between 0.35 and 0.70 , towards

7 diesel emission (Kavouras et al., 2001). A Flu/(Flu+Pyr) ratio higher than $>0.5$ indicates

8 towards diesel emission, whereas a lower ratio $(<0.5)$ indicates towards gasoline emission

9 (Rogge et al., 1993; Mandalakis et al., 2002, Fang et al., 2004). The present study shows

10 very low values of Flu/(Flu+Pyr) ratios and hence confirms the presence of gasoline

11 emission in the region. Khalili et al. (1995) and Guo et al. (2003) proposed a value of

$12 \mathrm{~B}[\mathrm{a}] \mathrm{P} /(\mathrm{B}[\mathrm{a}] \mathrm{P}+\mathrm{Chr})$ around 0.49 for diesel emission, and 0.73 for gasoline emission. Higher

13 ratio of $\mathrm{B}[\mathrm{b}] \mathrm{F} / \mathrm{B}[\mathrm{k}] \mathrm{F}$ and $\mathrm{B}[\mathrm{a}] \mathrm{P} / \mathrm{B}[$ ghi $] \mathrm{P}$ indicate towards diesel emission and traffic

14 emission (Pandey et al., 1999; Park et al., 2002); whereas a lower value $(<0.4)$ of

15 Ind/BghiP has been reported for gasoline emission while the ratio for diesel engines

16 approaches 1 (Caricchia et al., 1999). Following to the initial studies of Prahl (1984) and

17 Takada et al. (1996); Gogou et al., (1996) suggested that the ratio of the sum of 9 major

18 nonalkylated compounds or 'combustion $\quad$ PAHs'

$19(\mathrm{Flu}+\mathrm{Pyr}+\mathrm{B}[\mathrm{a}] \mathrm{A}+\mathrm{Chr}+\mathrm{B}[\mathrm{b}] \mathrm{F}+\mathrm{B}[\mathrm{k}] \mathrm{F}+\mathrm{B}[\mathrm{a}] \mathrm{P}+\mathrm{Ind}+\mathrm{B}[$ ghi $] \mathrm{P})$ indicated as CPAHs, to the total

20 concentration of EPA-PAHs (CPAHs/TPAHs) can be used to identify the combustion

21 sources. However, in the above studies additional PAHs (e.g. retene, methylated

22 phenanthrenes etc.) including most of the EPA- PAHs were analyzed. A CPAHs/TPAHs

23 ratio towards unity has been suggested for PAHs produced by combustion activities

24 (Manoli et al., 2004; Mantis et al., 2005; Ravindra et al., 2008). 
Comparison of our data to the various diagnostic ratios (Table 2) shows that the

2 emission from the diesel engines and combustion sources dominate the particulate PAHs

3 emission in Menen. This is also expected as $60 \%$ of the traffic in Belgium is powered by

4 diesel (MIRA, 2006). However the results also indicate that the emission from gasoline

5 engines and stationary sources (industrial/coal/wood) also influences the PAHs levels.

6 Further, it has to be noted that the CPAHs/TPAHs ratio varies significantly with the

7 variation in monthly average concentration of PAHs and hence it can be concluded that

8 increases in PAHs levels during winter seasons are likely to be associated with the

9 combustion activities as it approaches towards unity.

10 The diagnostic ratios should be used with caution because it is often difficult to

11 discriminate between some sources (Ravindra et al., 2008). The reactivity of some PAH

12 species with other atmospheric species, such as ozone and/or oxides of nitrogen can change

13 the diagnostic ratio (Robinson et al., 2006a,b). Liu et al. (2006) also reported that the

14 concentration of 5- to 7- ring PAHs were underestimated in non-denuded samples, which

15 are predominant in the aerosol phase. Further, Tsapakis and Stephanou, (2003) also

16 reported that the degradation of PAHs may occur during the sampling process and can also

17 modify their atmospheric levels. The difference in chemical reactivity, volatility and

18 solubility of PAH species may introduce bias but to minimize this error, the diagnostic ratio

19 with similar physico-chemical properties of PAHs should be used (Goriaux et al., 2006,

20 Ravindra 2008).

\section{Principal component analysis}

22 In order to improve the accuracy of the emission source identification, the method

23 of PCA was applied. The principle of PCA is to transform the original set of variables into

24 a smaller set of linear combinations that accounts for most of the variance of the original 
1 set. The primary function of this analysis is the reduction of the number of variables while

2 retaining the original information as much as possible. Thus variables with similar

3 characteristics can be grouped into factors. In the present study the source grouping were

4 determined using PCA with varimax rotation and retention of principal components having

5 an eigenvalue $>1$ of the complete data set of PAHs concentrations. Factor analysis in this

6 study was carried out using the statistical analysis SPSS 12.0 software package (Norusis,

7 and SPSS Inc, 2002).

Table 3 provides the results of factor analysis of total EPA-PAHs concentrations at

9 Menen. The PCA result shows that three factors explain the main part of the data variance.

10 The factor loading correlates the variables and represents the most important information

11 on which the interpretation of the factors is based. First factor is generally more correlated

12 with the variables than the second factors because these factors are extracted successively,

13 each one accounting for as much of remaining variables as possible. Factor 1 has a very

14 high factor loading of $\mathrm{B}[\mathrm{a}] \mathrm{A}, \mathrm{B}[\mathrm{a}] \mathrm{P}, \mathrm{B}[\mathrm{b}] \mathrm{F}, \mathrm{B}[$ ghi] $\mathrm{P}$ and Ind; which are identified as a

15 marker of gasoline emissions (Duval and Friedlander, 1981; Khalili et al., 1995; Park et at

16 al., 2002; Guo et al., 2003). A relatively high factor loading for Flut, PA, Ant and Pyr is an

17 indication of diesel emission (Yang et al., 1998; Caricchia et al., 1999; Kulkarini and

18 Venkataraman, 2000; Ho et al., 2002; Omar et al., 2002; Fang et al., 2004). Hence, it can be

19 suggested that vehicular emissions form a major fraction of PAHs at Menen. The high

20 factor loading of $\mathrm{Chr}$ and $\mathrm{B}[\mathrm{b}] \mathrm{F}$ indicates that stationary sources may also affect the PAHs

21 levels at Menen (Yang et al., 1998; Kulkarini and Venkataraman, 2000; Fang et al., 2004).

22 For factor 2, AcPy, PA Ant and Pyr had a loading factor around 0.5 or more,

23 indicating them to come from other sources than identified in factor 1. These PAHs have

24 been identified in emission from incinerator (Smith and Harrison, 1998; Ravindra et al., 
1 2006), coal combustion, coke production and wood combustion (Duval and Friedlander,

2 1981; Khalili et al., 1995, Lee et al., 2005). Van Lieshout et al. (2001) reported some open

3 fires and incinerator activities in the vicinity of Menen. The closest coke-ovens or steel

4 industry are situated in Sidmar (Zelzate) around $70 \mathrm{~km}$ in north of Menen and may not

5 influence the PAHs levels. The third factor is comprised of the lighter PAHs (Nap, AcPy

6 and Acp), which are prevalent in the vapor phase. Components related to the third factor

7 are not attributed to 'identified sources'. Based on the PCA variance distribution, the data

8 shows that vehicular sources contribute around 65\% of total EPA-PAHs levels at Menen;

9 whereas it account around 13\% from combustion (e.g. incinerator, wood burning).

10 However, the source type identified in this study mainly results from PAHs source

11 fingerprints in the literature, not from the local PAHs source profile. Up-to-date profiles of

12 emissions from local source categories should be collected to identify more reliable PAHs

13 source categories and to generate their quantitative source contribution.

\section{Impact of regional-global activities on PAHs levels}

15 Long-range transport of various organic pollutants was demonstrated in the 1980s

16 by Oehme and Mano (1984) but they mainly focus on vapor phase organic pollutants

17 including only fluoranthene. After this, only few efforts have been made to study the long

18 range transport of PAHs by measurement and use of various models. Some of the example

19 studies includes Halsall et al., 1997, 2001; Lee et al., 1999; Prevedouros et al., 2004a,b;

20 Jaward et al., 2004; Fenner et al., 2005; Park et al., 2006 etc. However, most of them were

21 specific for a day or episode. In the present study the approach has been elaborated over a

22 year period to study the influence of regional and global activities and emission sources on

2316 US EPA priority listed PAHs levels by backward air mass trajectories. The HYSPLIT- 
1 v4 model from NOAA Air Resources Laboratory (ARL) was used for computing

2 trajectories (Draxler and Hess, 1997). The trajectories were categorized based on their

3 origin and where they spend most of their 4 days traveled routes.

4 In this study, 4-day trajectory were computed every $6 \mathrm{~h}$ at an arrival point in Menen

$5 \quad\left(50^{\circ} 47^{\prime} \mathrm{N}, 3^{\circ} 6^{\prime} \mathrm{W}\right)$ during the year 2003 . The choice of a 4-day trajectory is a compromise

6 between the several-day atmospheric residence time of suspended particles and especially

7 of fine particles and the declining accuracy in calculation of the back trajectory (due to

8 model assumptions and spatial and temporal resolution of the meteorological data). Any

9 error associated with a single trajectory is reduced when daily trajectories are grouped

10 together according to the common path the air masses followed (Stohl, 1998). Therefore,

11 the 63 daily trajectories were assigned to ten categories: Benelux (BE), Atlantic (AT),

12 Arctic (AR), United Kingdom (UK), Central Europe (CE), Western Europe (WE),

13 Scandinavia (SC), Maritime (MT), Eastern Europe (EE) and Unclassified (UC); using the

14 criteria as mentioned in Table 4. The representative day specific examples of these

15 categories are shown in Figure 2, which shows that the levels of PAHs likely increase when

16 there is an air mass movement from Central and Western Europe and fall when the

17 trajectories spend most of their 4 days in the Arctic region or over the Atlantic Ocean

18 (Table 4).

19 Jaward et al. (2004) reported that B[a]P inventory shows the highest loading in

20 Eastern Europe (e.g. Poland, parts of Russia, and the Czech Republic), and the more

21 populated and industrialized areas of western Europe (e.g. parts of United Kingdom and

22 The Netherlands). These hotspots of PAH emissions are also evidenced from Figure 3,

23 where predicted mean annual B[a]P concentrations are shown over Europe (EMEP, 2007).

24 Furthermore, Figure 4 shows the predicted or modeled levels of PAHs in the air of Belgium 
1 (EMEP, 2007). However, the modeled and measured levels varied significantly but the

2 distribution pattern of PAHs seem in agreement with the present study (Table 4) and a 3 study by Ravindra et al. (2006a). A study of Ravindra et al. (2006a) and an inventory

4 studied done by Flemish Institute for Technological Research (www.vito.be) under MIRA 5 project (2006) found that transport and household emission were the major source of PAHs 6 in Belgium during 2005 [transport (83 ton); household (74 ton); industries (15 ton); other (2 7 ton)]. Further this report shows a decreasing emission trends from 1990 to 2005 . However, 8 a recent inventory by Breivik et al. (2006) suggest "residential heating plants" as a key 9 source of PAHs in Europe and in contrary to MIRA report an increasing trend of PAHs for 10 Belgium.

11 Only few countries in Europe have proposed a recommended (but non mandatory) 12 value of PAHs using B[a]P as a surrogate for all PAHs (Ravindra et al., 2008). These 13 proposed value ranged from 0.25 to $2 \mathrm{ng} / \mathrm{m}^{3}$ on annual average basis (PAHs position paper, 14 2001). These countries are Belgium $\left(1.0 \mathrm{ng} / \mathrm{m}^{3}\right)$, Croatia $\left(2.0 \mathrm{ng} / \mathrm{m}^{3}\right)$, France $\left(0.7 \mathrm{ng} / \mathrm{m}^{3}\right)$,

15 Germany $\left(1.3 \mathrm{ng} / \mathrm{m}^{3}\right)$, Italy $\left(1.0 \mathrm{ng} / \mathrm{m}^{3}\right)$, Netherlands $\left(1.0 \mathrm{ng} / \mathrm{m}^{3}\right)$ and UK $\left(0.25 \mathrm{ng} / \mathrm{m}^{3}\right)$. As 16 shown in this study, both regional and global activities influence the levels of PAHs and 17 there is increasing evidence of their carcinogenic, mutagenic and or teratogenic nature 18 (Ravindra et al., 2001; Lewtas et al., 2007; Sram et al., 2007a,b). Hence it is suggested to 19 have a uniform policy (e.g. similar air quality standard of PAHs) for all European nations to 20 curb PAHs pollution.

\section{Conclusions}

22 Particulate samples, collected during 2003, were extracted very fast by PLE and 23 subsequently analyzed by HPLC for 16 US EPA criteria PAHs. The analytical results show 
1 that the high molecular weight PAHs such as Flut, Chr, B[b]F, B[a]P, B[ghi]P and Ind,

2 dominate the total fraction, whereas low molecular weight PAHs were found in relatively

3 very low concentration and only Nap and PA show a significant presence. Further, the

4 reported daily PAHs concentrations were relatively high when the prevailing wind direction

5 were SW at Menen Seasonal and meteorological parameter also play a role to limit the

6 PAHs concentration and generally a higher concentration of PAHs in the winter season was

7 found. The higher concentration in winter mainly indicates its relation with increased

8 emission from domestic heating and power plants with low temperature (i.e. different

9 emission sources in winter and summer). Furthermore, enhanced sorption to particles at

10 lower temperature (as a result of reduced vapor pressure) and reduced vertical dispersion

11 due to inversion may also influence the PAHs levels. However the concentration of

12 indicative PAHs i.e. B[a]P was found lower than its proposed maximum value $\left(1 \mathrm{ng} / \mathrm{m}^{3}\right)$ at

13 Menen, but the health risk associated with them can not be ignored, especially during 14 winter.

15 The application of correlation coefficient calculation, diagnostics ratio and PCA 16 allowed to find the possible sources of PAHs, which indicate towards vehicular emission as 17 major source although other sources like incinerator and wood burning (specially during 18 winter) may also exist. The variations in PAHs levels studied with relation to 19 transboundary movement of air masses show a clear relation with the hotspots of PAH 20 emissions, which were identified in EMEP studies. However the health risk studies 21 conducted with relation to PAHs exposure urges to include these pollutants as top priority 22 for air quality management but till date only few countries have proposed a (non23 mandatory) limit for PAHs. 


\section{Acknowledgement}

3 The authors thank all the 5 anonymous referees for their constructive comments. This study 4 presents a part of the results obtained in the project "Measurement campaigns in Euro 5 region 2002-2004", a study realized with the help of the European program INTERREG III.

6 The action was included in an INTERREG project called "EXposition des Populations

7 vivants au coeur de l'Euro-Région aux polluants atmosphériques : le cas des Poussières

8 Fines" whose abbreviation is EXPER/PF. The authors gratefully acknowledge the NOAA

9 Air Resources Laboratory (ARL) for the HYSPLIT-v4 model used in this publication. 


\section{References}

Agency for Toxic Substances and Disease Registry (ATSDR). 1995. Toxicological profile for polycyclic aromatic hydrocarbons (PAHs). Atlanta, GA: U.S. Department of Health and Human Services, Public Health Service. http://www.atsdr.cdc.gov/toxprofiles/tp69.html

Beverland, I.J., Tunes, T., Sozanska, M., Elton, R.A., Agius, R.M., Heal, M.R., 2000. Effect of long-range transport on local PM10 concentrations in the UK. International Journal of Environmental Health Research 10, 229-238.

Binkova, B., Vesely, D., Vesela, D., Jelinek, R., Sram, R.J., 1999. Genotoxicity and embryotoxicity of urban air particulate matter collected during winter and summer period in two different districts of the Czech Republic

Mutation Research 440, 45-58. 1999

Binkova, B,, Cerna, M., Pastorkova, A., Jelinek, R., Benes, I., Novak, J., Sram, R,J., 2003. Biological activities of organic compounds adsorbed onto ambient air particles: comparison between the cities of Teplice and Prague during the summer and winter seasons 2000-2001 Mutation Research 525, 43-59.

Breivik K., Vestreng V., Rozovskaya O., Pacyna, J.M., 2006. Atmospheric emission of existing inventories and data need. Environmental Science and Policy, 9, 663-674.

Bruske-Hohlfeld, I, Mohner M, Pohlabeln H, Ahrens W, Bolm-Audorff U, Kreienbrock L, Kreuzer M, Jahn I, Wichmann HE, Jockel KH. Occupational lung cancer risk for men in Germany: results from a pooled case-control study. American Journal of Epidemiology 2000, 15, 384-395.

Buchanan, C.M., Beverland, I.J., Heal, M.R., 2002. The influence of weather-type and long-range transport on airborne particle concentrations in Edinburgh, UK. Atmospheric Environment 36, 5343-5354.

Caricchia, A.M., Chiavarini, S., Pezza, M., 1999. Polycyclic aromatic hydrocarbons in the urban atmospheric particulate matter in the city of Naples (Italy). Atmospheric Environment 33, 3731-3738.

Draxler, R.R., Hess, D.G., 1997. NOAA Technical Memorandum ERL ARL-224 Description of the HYSPLIT-4 Modeling System". Air Resources Laboratory Silver Spring, Maryland, http://www.arl.noaa.gov/data/web/models/hysplit4/win95/arl-224.pdf.

Duval, M.M., Friedlander, S.K., 1981. Source resolution of polycyclic aromatic hydrocarbons in Los Angeles atmosphere - application of CMB with first order decay. US EPA Report No EPA-600/2-81-161.

EMEP (A scientifically based and policy driven program under the Convention on Longrange Transboundary Air Pollution for international co-operation to solve transboundary air pollution problems), 2007. http://www.msceast.org/about.html 
EPA, 1994. Peer Review and Peer Involvement at the U.S. Environmental Protection Agency, Science Policy Council, Office of the Science Advisor, Environmental Protection Agency. ID 2872. http://epa.gov/osa/spc/htm/perevmem.htm

Fang, G.C., Wu, Y.S., Chen, M.H., Ho, T.T., Huang, S.H., Rau, J.Y., 2004. Polycyclic aromatic hydrocarbons study in Taichung, Taiwan, during 2002-2003, Atmospheric Environment 38, 3385-3391.

Fenner, K., Scheringer, M., MacLeod, M., Matthies, M., McKone, T.E., Stroebe, M., et al. 2005. Comparing estimates of persistence and longrange transport potential among multimedia models. Environmental Science and Technologyl 39, 1932-42.

Gerde P, Muggenburg BA, Lundborg M, Dahl AR. The rapid alveolar absorption of diesel soot-adsorbed benzo[a]pyrene: bioavailability, metabolism and dosimetry of an inhaled particle-borne carcinogen. Carcinogenesis 2001, 22, 741-749.

Godoi, A.F.L., Ravindra, K., Godoi, R.H.M., Andrade, S.J., Santiago-Silva, M., Van Vaeck, L., Van Grieken, R., 2004. Fast Chromatographic determination of polycyclic aromatic hydrocarbon in aerosol samples from sugar cane burning. Journal of Chromatography A, 1027, (1-2), 49-53.

Gogou, A., Stratigakis, N., Kanakidou, M., Stephanou, E.G., 1996. Organic aerosols in Eastern Mediterranean: Components source reconciliation by using molecular markers and atmospheric back trajectories. Organic Geochemistry, 25, 79-96.

Goriaux, M., Jourdain, B., Temime, B., Besombes, J.-L., Marchand, N., Albinet, A., LeozGarziandia, E., Wortham, H., 2006. Field comparison of PAH measurements using a low flow denudeur device and conventional sampling systems. Environmental Sciences and Technology, 40, 6398-6404.

Graham, B., Falkovich, A.H., Rudich, Y., Maenhaut, W., Guyon, P., Andreae, M.O., 2004, Local and regional contributions to the atmospheric aerosol over Tel Aviv, Israel: a case study using elemental, ionic and organic tracers, Atmospheric Environment 38, 1593-1604.

Grennfelt, P., Hov, O., 2005. Regional air pollution at a turning point, AMBIO 34, 2-10.

Grimmer, G., Jacob J., Naujack K.W., 1983. Profile of the polycyclic aromatic compounds from crude oils- Inventory by GC GC-MS. PAH in environmental materials, part 3. Fresenius Journal of Analytical Chemistry 316, 29-36.

Guo, H., Lee, S.C., Ho, K.F., Wang, X.M., Zou, S.C., 2003. Particle-associated polycyclic aromatic hydrocarbons in urban air of Hong Kong. Atmospheric Environment 37, 53075317.

Halsall, C.J., Barrie, L.A., Fellin, P., Muir, D.C.G., Billeck, B.N., Lockhart, L., Rovinsky, F.Ya., Kononov, E.Ya., Pastukhov, B., 1997. Spatial and temporal variation of polycyclic 
1 aromatic hydrocarbons in the Arctic atmosphere. Environmental Science and Technology 31, 3593-3599.

Halsall, C.J., Sweetman, A.J., Barrie, L.A., Jones, K.C., 2001. Modelling the behaviour of PAHs during atmospheric transport from the UK to the Arctic. Atmospheric Environment 35, 255-267.

Ho, K.F., Lee, S.C., Chiu, G.M.Y., 2002. Characterization of selected volatile organic compounds, polycyclic aromatic hydrocarbons and carbonyl compounds at a roadside monitoring station. Atmospheric Environment 36, 57-65.

Jaward, F.M., Farrar, N.J., Harner, T., Sweetman, A.J., Jones, K.C., 2004. Passive air sampling of polycyclic aromatic hydrocarbons and polychlorinated naphthalenes across Europe. Environmental Toxicology and Chemistry 23, 1355-1364.

Kavouras, I.G., Koutrakis, P., Tsapakis, M., Lagoudaki, E., Stephanou, E.G., Von Baer, D., Oyola, P., 2001. Source apportionment of urban particulate aliphatic and polynuclear aromatic hydrocarbons (PAHs) using multivariate methods. Environmental Science and Technology 35, 2288-2294.

Khalili, N.R., Scheff, P.A., Holsen, T.M., 1995. PAH source fingerprints for coke ovens, diesel and gasoline engines, highway tunnels, and wood combustion emissions. Atmospheric Environment 29, 533-542.

Kulkarni, P., Venkataraman, C., 2000. Atmospheric polycyclic aromatic hydrocarbons in Mumbai, India. Atmospheric Environment 34, 2785-2790.

Lee, R.G.M., Coleman, P., Jones, J.L., Jones, K.C., Lohmann, R., 2005. Emission factors and importance of PCDD/Fs, PCBs, PCNs, PAHs and PM10 from the domestic burning of coal and wood in the U.K. Environmental Science and Technology 39, 1436-1447.

Lee, R.G.M., Jones, K.C., 1999. The influence of meteorology and air masses on daily atmospheric concentration at a UK location. Environmental Science and Technology, 33, 705-712.

Lewtas, J., 1993. Complex mixtures of air pollutants: characterizing the cancer risk of polycyclic organic matter. Journal of Environmental Health 100, 211-8.

Lewtas, J., 2007. Air pollution combustion emissions: Characterization of causative agents and mechanisms associated with cancer, reproductive, and cardiovascular effects. Mutatation Research 636, 95-133.

Ligocki, M.P. Pankow, J.F., 1989. Meassurments of the gas particle distribution of atmospheric organic compounds. Environmental Science and Technology 23, 75-83

Liu, Y., Sklorz, M., Schnelle-Kreis, J., Orasche, J., Ferge, T., Kettrup, A., Zimmermann, R., 2006. Oxidant denuder sampling for analysis of polycyclic aromatic hydrocarbons and 
their oxygenated derivates in ambient aerosol: evaluation of sampling artefact. Chemosphere 62, 1889-1898.

Manahan S.E. Environmental Chemistry, $6^{\text {th }}$ Ed., Lewis Publisher, New York, 1994.

Mandalakis, M., Tsapakis, M., Tsoga, A., Stephanou, E.G., 2002. Gas-particle concentrations and distribution of aliphatic hydrocarbons, PAHs, PCBs and PCDD/Fs in the atmosphere of Athens (Greece). Atmospheric Environment 36, 4023-4035.

Mantis, J., Chaloulakou, A., Samara, C., 2005. PM10-bound polycyclic aromatic hydrocarbons (PAHs) in the greater area of Athens, Greece, Chemosphere 59, 593-604.

Manoli, E., Kouras, A., Samara, C., 2004. Profile analysis of ambient and source emitted particle-bound polycyclic aromatic hydrocarbons from three sites in northern Greece. Chemosphere 56, 867-878

MIRA (2006). Milieurapport (Environmental Report), In Dutch. Flemish Environmental Agency, Mechelen, Belgium. (www.vmm.be/mira or www.milieurapport.be

Nielsen T, Jorgensen HE, Larsen JC, and Poulsen M. City air pollution of polycyclic aromatic hydrocarbons and other mutagens: occurrence, sources, and health effect. The Science of the Total Environment 1996; 189-190: 41-49.

Oehme, M., Mano, S., 1984. The long-range transport of organic pollutants to the Arctic. Fresenius' Journal of Analytical Chemistry, 319,141-146.

PAHs position paper, 2001. Ambient Air Pollution by Polycyclic Aromatic Hydrocarbons (PAH). Office for Official Publications of the European Communities, Luxembourg.

Pandey, P.K., Patel, K.S., Lenicek, J., 1999. Polycyclic aromatic hydrocarbons: Need for assessment of health risks in India? -Study of an urban-industrial location in India. Environmental Monitoring and Assessment 59, 287-319.

Park, S.S., Bae, M.S., Schaue,r J.J., Kim, Y.J., Cho, S.Y., Kim, S.J., 2006. Molecular composition of PM2.5 organic aerosol measured at an urban site of Korea during the ACEAsia campaign. Atmospheric Environment, 40, 4182-4198.

Park, S.S., Kim, Y.J., Kang, C.H., 2002. Atmospheric polycyclic aromatic hydrocarbons in Seoul, Korea. Atmospheric Environment 36, 2917-2924.

Prahl, F.G., Crecellus, E., Carpenter, R., 1984. Polycyclic aromatic hydrocarbons in Washington coastal sediments: an evaluation of atmospheric and riverine routes of introduction. Environmental Science and Technology 18, 687- 693.

Prevedouros, K., Jones, K.C., Sweetman, A.J., 2004. Modelling the atmospheric fate and seasonality of polycyclic aromatic hydrocarbons in the UK. Chemosphere 56, 195-208. 
Prevedouros, K., Brorstrom-Lunden, E., Halsall, C.J., Jones, K.C., Lee, R.G.M., Sweetman, A.J., 2004. Seasonal and long-term trends in atmospheric PAH concentrations: evidence and implications. Environmental Pollution 128, 17-27.

Ravindra, K., Bencs, L., Wauters, E., de Hoog, J., Deutsch, F., Roekens, E., Bleux, N., Bergmans P., Van Grieken, R., 2006 a. Seasonal and site specific variation in vapor and aerosol phase PAHs over Flanders (Belgium) and their relation with anthropogenic activities. Atmospheric Environment 40, 771-785.

Ravindra, K., Mittal, A.K., Van Grieken, R., 2001. Health risk assessment of urban suspended particulate matter with special reference to polycyclic aromatic hydrocarbons: A review. Reviews on Environmental Health 16, 169-189.

Ravindra, K., Wauters, E., Taygi, S.K., Mor, S., Van Grieken R., 2006 b. Assessment of air quality after the implementation of $\mathrm{CNG}$ as fuel in public transport in Delhi, India. Environmental Monitoring and Assessment 115, 405-417.

Ravindra, K., R.S. Sokhi, Van Grieken, R., 2008. Atmospheric Polycyclic Aromatic Hydrocarbons: Source attribution, emission factors and regulation. Atmospheric Environment, doi: 10.1016/j.atmosenv.2007.12.010

Robinson, A.L., Donahue, N.M., Rogge, W.F., 2006a. Photochemical oxidation and changes in molecular composition of organic aerosol in the regional context. Journal of Geophysical Research 111, D03302.

Robinson, A.L., Subramanian, R., Donahue, N. M., Bernardo- Bricker, A., Rogge, W. F., 2006b. Source apportionment of molecular markers and organic aerosols1. Polycyclic aromatic hydrocarbons and methodology for data visualization. Environmental Science and Technology 40, 7813-7820.

Rogge, W.F., Hildemann, L.M., Mazurek, M.A., Cass, G.R., Simoneit, B.R.T., 1993. Sources of fine organic aerosol: 2. Noncatalyst and catalyst-equipped automobiles and heavy-duty diesel trucks. Environmental Science and Technology 27, 636-651.

Norusis, M. J. and SPSS Inc., SPSS for Windows Professional Statistics 7.5, Prentice Hall, Englewood Cliffs, 2002.

Sklorz, M., Schnelle-Kreis, Liu Y. J., Orasche, J.,Zimmermann, R., 2007. Daytime resolved analysis of polycyclic aromatic hydrocarbonsin urban aerosol samples - Impact of sources and meteorological conditions. Chemosphere 67 934-943

Stohl, A., 1998. Computation, accuracy and applications of trajectories-a review and bibliograph y. Atmospheric Environment 32, 947-966.

Sram, R.J., Beskid, O., Binkova, B., Chvatalova, I., Lnenickova, Z., Milcova, A., Solansky, 46 I., Tulupova, E., Bavorova, H., Ocadlikova, D., Farmer, P.B., 2007a. Chromosomal 
1 aberrations in environmentally exposed population in relation to metabolic and DNA repair

2 genes polymorphisms, Mutatation Research 620, 22-33.

Sram, R.J., Beskid, O., Rossnerova, A., Rossner, P., Lnenickova, Z., Milcova, A., Solansky, I., Binkova, B., 2007b. Environmental exposure to carcinogenic polycyclic aromatic hydrocarbons - The interpretation of cytogenetic analysis by FISH. Toxicology letters 172, 12-20.

Takada, H., Onda T. Ogura, N., 1990. Determination of polycyclic aromatic hydrocarbons in urban street dusts and their source materials by capillary gas chromatography. Environmental Science and Technology 24, 1179-1186.

Tsapakis, M., Stephanou, E.G., 2003. Collection of gas and particle semi-volatile organic compounds: use of an oxidant denuder to minimize polycyclic aromatic hydrocarbons degradation during high-volume air sampling. Atmospheric Environment 37, 4935-4944.

Van Lieshout, L., Desmedt, M., Roekens, E., De Fré, R.., Van Cleuvenbergen, R., Wevers, M., 2001. Deposition of dioxins in Flanders (Belgium) and a proposition for guide values. Atmospheric Environment 35, 83-90.

Venkataraman, C., Lyons, J.M., Friedlander, S.K., 1994. Size distributions of aromatic hydrocarbons and elemental carbon. 1. Sampling, measurement methods and source characterization. Environmental Science and Technology 28, 555-562.

World Health Organization (WHO). Guideline for air quality 2000, Geneva.

Yang, H.H., Lee, W.J., Chen, S.J., Lai, S.O., 1998. PAH emission from various industrial stacks. Journal of Hazardous Materials 60, 159-174.

Yamasaki, H., Kuwata, K., Miyamoto, H., 1982: Effects of ambient temperature on aspects of airborne polycyclic aromatic hydrocarbons. Environmental Science and Technology16, $189-194$ 
Table 1: Monthly average concentration $\left(\mathrm{ng} / \mathrm{m}^{3}\right)$ of individual PAHs at Menen.

\begin{tabular}{|c|c|c|c|c|c|c|c|c|c|c|c|c|c|c|c|c|}
\hline \multirow[b]{2}{*}{ Months } & \multicolumn{16}{|c|}{ Monthly Average Concentration of Individual PAHs } \\
\hline & ڤ్ & $\frac{8}{2}$ & $\frac{8}{8}$ & $\underline{z}$ & $D$ & $\underset{Z}{Z}$ & $\underline{\Xi}$ & 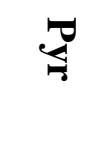 & $\frac{\pi}{D}$ & 尺 & $\frac{\sigma}{\sigma}$ & $\frac{\pi}{\bar{\pi}}$ & $\frac{\pi}{\theta}$ & $\frac{\theta}{\frac{\theta}{D}}$ & $\frac{\sigma}{\frac{\sigma \theta}{\sigma \theta}}$ & 클 \\
\hline anuary & $\begin{array}{c}0.13 \\
\pm 0.07\end{array}$ & $\begin{array}{c}0.03 \\
\pm 0.02\end{array}$ & $\begin{array}{c}0.04 \\
\pm 0.03\end{array}$ & $\begin{array}{c}0.04 \\
\pm 0.03\end{array}$ & $\begin{array}{c}0.08 \\
\pm 0.06\end{array}$ & $\begin{array}{c}0.01 \\
\pm 0.01\end{array}$ & $\begin{array}{c}2.28 \\
\pm 3.34\end{array}$ & $\begin{array}{c}0.31 \\
\pm 0.29\end{array}$ & $\begin{array}{c}0.81 \\
\pm 1.29\end{array}$ & $\begin{array}{c}2.20 \\
\pm 3.20\end{array}$ & $\begin{array}{c}1.79 \\
\pm 2.46\end{array}$ & $\begin{array}{c}0.80 \\
\pm 1.10\end{array}$ & $\begin{array}{c}1.35 \\
\pm 2.11\end{array}$ & $\begin{array}{c}0.37 \\
\pm 0.50\end{array}$ & $\begin{array}{c}1.49 \\
\pm 2.23\end{array}$ & $\begin{array}{r}1.51 \\
\pm 2.08\end{array}$ \\
\hline February & $\begin{array}{c}0.20 \\
\pm 0.14\end{array}$ & $\begin{array}{c}0.17 \\
\pm 0.27\end{array}$ & $\begin{array}{c}0.09 \\
\pm 0.03\end{array}$ & $\begin{array}{c}0.03 \\
\pm 0.02\end{array}$ & $\begin{array}{c}0.73 \\
\pm 0.93\end{array}$ & $\begin{array}{c}0.10 \\
\pm 0.10\end{array}$ & $\begin{array}{c}2.30 \\
\pm 2.23\end{array}$ & $\begin{array}{c}1.32 \\
\pm 1.46\end{array}$ & $\begin{array}{c}0.97 \\
\pm 0.72\end{array}$ & $\begin{array}{c}2.33 \\
\pm 1.83\end{array}$ & $\begin{array}{c}1.76 \\
\pm 1.27\end{array}$ & $\begin{array}{c}0.81 \\
\pm 0.59\end{array}$ & $\begin{array}{c}1.40 \\
\pm 1.28\end{array}$ & $\begin{array}{c}0.52 \\
\pm 0.57\end{array}$ & $\begin{array}{c}1.77 \\
\pm 1.44\end{array}$ & $\begin{array}{c}1.72 \\
\pm 1.22\end{array}$ \\
\hline March & $\begin{array}{c}0.22 \\
\pm 0.18\end{array}$ & $\begin{array}{c}0.04 \\
\pm 0.02\end{array}$ & $\begin{array}{c}0.07 \\
\pm 0.03\end{array}$ & $\begin{array}{c}0.03 \\
\pm 0.02\end{array}$ & $\begin{array}{c}0.22 \\
\pm 0.20\end{array}$ & $\begin{array}{c}0.04 \\
\pm 0.03\end{array}$ & $\begin{array}{c}0.28 \\
\pm 0.18\end{array}$ & $\begin{array}{c}0.44 \\
\pm 0.23\end{array}$ & $\begin{array}{c}0.48 \\
\pm 0.25\end{array}$ & $\begin{array}{c}0.67 \\
\pm 0.24\end{array}$ & $\begin{array}{c}0.82 \\
\pm 0.28\end{array}$ & $\begin{array}{c}0.36 \\
\pm 0.14\end{array}$ & $\begin{array}{c}0.43 \\
\pm 0.19\end{array}$ & $\begin{array}{c}0.38 \\
\pm 0.32\end{array}$ & $\begin{array}{c}0.92 \\
\pm 0.40\end{array}$ & $\begin{array}{c}0.77 \\
\pm 0.33\end{array}$ \\
\hline April & $\begin{array}{c}0.19 \\
\pm 0.18\end{array}$ & $\begin{array}{c}0.03 \\
\pm 0.02\end{array}$ & $\begin{array}{c}0.03 \\
\pm 0.02\end{array}$ & $\begin{array}{c}0.03 \\
\pm 0.02\end{array}$ & $\begin{array}{c}0.29 \\
\pm 0.23\end{array}$ & $\begin{array}{c}0.05 \\
\pm 0.06\end{array}$ & $\begin{array}{c}0.63 \\
\pm 0.24\end{array}$ & $\begin{array}{c}0.19 \\
\pm 0.23\end{array}$ & $\begin{array}{c}0.22 \\
\pm 0.26\end{array}$ & $\begin{array}{c}0.52 \\
\pm 0.28\end{array}$ & $\begin{array}{c}0.57 \\
\pm 0.30\end{array}$ & $\begin{array}{c}0.24 \\
\pm 0.13\end{array}$ & $\begin{array}{c}0.32 \\
\pm 0.16\end{array}$ & $\begin{array}{c}0.10 \\
\pm 0.09\end{array}$ & $\begin{array}{c}0.44 \\
\pm 0.32\end{array}$ & $\begin{array}{c}0.59 \\
\pm 0.33\end{array}$ \\
\hline & $\begin{array}{c}0.14 \\
\pm 0.05\end{array}$ & $\begin{array}{c}0.10 \\
\pm 0.15\end{array}$ & $\begin{array}{c}0.09 \\
\pm 0.07\end{array}$ & $\begin{array}{c}0.02 \\
\pm 0.01\end{array}$ & $\begin{array}{c}0.09 \\
\pm 0.05\end{array}$ & $\begin{array}{c}0.03 \\
\pm 0.02\end{array}$ & $\begin{array}{c}0.21 \\
\pm 0.18\end{array}$ & $\begin{array}{c}0.16 \\
\pm 0.15\end{array}$ & $\begin{array}{c}0.30 \\
\pm 0.17\end{array}$ & $\begin{array}{c}0.25 \\
\pm 0.12\end{array}$ & $\begin{array}{c}0.30 \\
\pm 0.17\end{array}$ & $\begin{array}{c}0.14 \\
\pm 0.08\end{array}$ & $\begin{array}{c}0.15 \\
\pm 0.10\end{array}$ & $\begin{array}{c}0.10 \\
\pm 0.11\end{array}$ & $\begin{array}{c}0.28 \\
\pm 0.21\end{array}$ & $\begin{array}{r}0.27 \\
\pm 0.26\end{array}$ \\
\hline une & $\begin{array}{c}0.10 \\
\pm 0.02\end{array}$ & $\begin{array}{c}0.02 \\
\pm 0.01\end{array}$ & $\begin{array}{c}0.10 \\
\pm 0.07\end{array}$ & $\begin{array}{c}0.02 \\
\pm 0.01\end{array}$ & $\begin{array}{c}0.14 \\
\pm 0.11\end{array}$ & $\begin{array}{c}0.05 \\
\pm 0.04\end{array}$ & $\begin{array}{c}0.17 \\
\pm 0.01\end{array}$ & $\begin{array}{c}0.04 \\
\pm 0.00\end{array}$ & $\begin{array}{c}0.03 \\
\pm 0.00\end{array}$ & $\begin{array}{c}0.23 \\
\pm 0.04\end{array}$ & $\begin{array}{c}0.27 \\
\pm 0.06\end{array}$ & $\begin{array}{c}0.11 \\
\pm 0.04\end{array}$ & $\begin{array}{c}0.12 \\
\pm 0.01\end{array}$ & $\begin{array}{c}0.08 \\
\pm 0.01\end{array}$ & $\begin{array}{c}0.16 \\
\pm 0.06\end{array}$ & $\begin{array}{c}0.21 \\
\pm 0.08\end{array}$ \\
\hline August & $\begin{array}{c}0.08 \\
\pm 0.04\end{array}$ & $\begin{array}{c}0.02 \\
\pm 0.01\end{array}$ & $\begin{array}{c}0.11 \\
\pm 0.06\end{array}$ & $\begin{array}{c}0.02 \\
\pm 0.01\end{array}$ & $\begin{array}{c}0.07 \\
\pm 0.09\end{array}$ & $\begin{array}{c}0.01 \\
\pm 0.01\end{array}$ & $\begin{array}{c}0.26 \\
\pm 0.27\end{array}$ & $\begin{array}{c}0.07 \\
\pm 0.03\end{array}$ & $\begin{array}{c}0.02 \\
\pm 0.02\end{array}$ & $\begin{array}{c}0.11 \\
\pm 0.05\end{array}$ & $\begin{array}{c}0.15 \\
\pm 0.12\end{array}$ & $\begin{array}{c}0.06 \\
\pm 0.04\end{array}$ & $\begin{array}{c}0.06 \\
\pm 0.04\end{array}$ & $\begin{array}{c}0.06 \\
\pm 0.03\end{array}$ & $\begin{array}{c}0.05 \\
\pm 0.03\end{array}$ & $\begin{array}{c}0.08 \\
\pm 0.06\end{array}$ \\
\hline September & $\begin{array}{c}0.20 \\
\pm 0.14\end{array}$ & $\begin{array}{c}0.03 \\
\pm 0.03\end{array}$ & $\begin{array}{c}0.07 \\
\pm 0.04\end{array}$ & $\begin{array}{c}0.03 \\
\pm 0.01\end{array}$ & $\begin{array}{c}0.18 \\
\pm 0.16\end{array}$ & $\begin{array}{c}0.06 \\
\pm 0.05\end{array}$ & $\begin{array}{c}0.29 \\
\pm 0.18\end{array}$ & $\begin{array}{c}0.15 \\
\pm 0.07\end{array}$ & $\begin{array}{c}0.28 \\
\pm 0.15\end{array}$ & $\begin{array}{c}0.32 \\
\pm 0.15\end{array}$ & $\begin{array}{c}0.38 \\
\pm 0.18\end{array}$ & $\begin{array}{c}0.18 \\
\pm 0.08\end{array}$ & $\begin{array}{c}0.20 \\
\pm 0.12\end{array}$ & $\begin{array}{c}0.17 \\
\pm 0.16\end{array}$ & $\begin{array}{c}0.37 \\
\pm 0.18\end{array}$ & $\begin{array}{c}0.36 \\
\pm 0.21\end{array}$ \\
\hline October & $\begin{array}{c}0.09 \\
\pm 0.04\end{array}$ & $\begin{array}{c}0.12 \\
\pm 0.11\end{array}$ & $\begin{array}{c}0.10 \\
\pm 0.05\end{array}$ & $\begin{array}{c}0.03 \\
\pm 0.02\end{array}$ & $\begin{array}{c}0.14 \\
\pm 0.14\end{array}$ & $\begin{array}{c}0.02 \\
\pm 0.01\end{array}$ & $\begin{array}{c}0.82 \\
\pm 0.52\end{array}$ & $\begin{array}{c}0.24 \\
\pm 0.18\end{array}$ & $\begin{array}{c}0.27 \\
\pm 0.10\end{array}$ & $\begin{array}{c}0.63 \\
\pm 0.33\end{array}$ & $\begin{array}{c}0.70 \\
\pm 0.26\end{array}$ & $\begin{array}{c}0.33 \\
\pm 0.12\end{array}$ & $\begin{array}{c}0.53 \\
\pm 0.22\end{array}$ & $\begin{array}{c}0.29 \\
\pm 0.16\end{array}$ & $\begin{array}{c}0.65 \\
\pm 0.27\end{array}$ & $\begin{array}{c}0.70 \\
\pm 0.31\end{array}$ \\
\hline & $\begin{array}{c}0.10 \\
\pm 0.01\end{array}$ & $\begin{array}{c}0.03 \\
\pm 0.03\end{array}$ & $\begin{array}{c}0.05 \\
\pm 0.04\end{array}$ & $\begin{array}{c}0.02 \\
\pm 0.01\end{array}$ & $\begin{array}{c}0.06 \\
\pm 0.04\end{array}$ & $\begin{array}{c}0.05 \\
\pm 0.01\end{array}$ & $\begin{array}{c}0.66 \\
\pm 0.29\end{array}$ & $\begin{array}{c}0.17 \\
\pm 0.01\end{array}$ & $\begin{array}{c}0.19 \\
\pm 0.01\end{array}$ & $\begin{array}{c}0.86 \\
\pm 0.06\end{array}$ & $\begin{array}{c}1.05 \\
\pm 0.05\end{array}$ & $\begin{array}{c}0.46 \\
\pm 0.02\end{array}$ & $\begin{array}{c}0.62 \\
\pm 0.08\end{array}$ & $\begin{array}{c}0.30 \\
\pm 0.07\end{array}$ & $\begin{array}{c}0.78 \\
\pm 0.11\end{array}$ & $\begin{array}{r}1.06 \\
\pm 0.02\end{array}$ \\
\hline December & $\begin{array}{c}0.19 \\
\pm 0.22\end{array}$ & $\begin{array}{c}0.05 \\
\pm 0.07\end{array}$ & $\begin{array}{c}0.07 \\
\pm 0.04\end{array}$ & $\begin{array}{c}0.02 \\
\pm 0.02\end{array}$ & $\begin{array}{c}0.06 \\
\pm 0.06\end{array}$ & $\begin{array}{c}0.04 \\
\pm 0.06\end{array}$ & $\begin{array}{c}1.27 \\
\pm 2.05\end{array}$ & $\begin{array}{c}0.33 \\
\pm 0.53\end{array}$ & $\begin{array}{c}0.62 \\
\pm 1.16\end{array}$ & $\begin{array}{c}1.45 \\
\pm 2.31\end{array}$ & $\begin{array}{c}1.40 \\
\pm 1.98\end{array}$ & $\begin{array}{c}0.64 \\
\pm 0.92\end{array}$ & $\begin{array}{c}1.25 \\
\pm 2.15\end{array}$ & $\begin{array}{c}0.55 \\
\pm 1.03\end{array}$ & $\begin{array}{c}1.17 \\
\pm 2.05\end{array}$ & $\begin{array}{c}1.27 \\
\pm 1.91\end{array}$ \\
\hline Average & $\begin{array}{c}0.17 \\
\mathbf{+ 0 . 0 5}\end{array}$ & $\begin{array}{c}0.06 \\
\mathbf{0} 0.05\end{array}$ & $\begin{array}{c}0.07 \\
\mathbf{\pm 0 . 0 3}\end{array}$ & $\begin{array}{c}0.03 \\
\mathbf{0} 0.01 \\
\end{array}$ & $\begin{array}{c}0.20 \\
\pm 0.19\end{array}$ & $\begin{array}{c}0.04 \\
\mathbf{\pm 0 . 0 2}\end{array}$ & $\begin{array}{c}0.84 \\
\pm 0.79\end{array}$ & $\begin{array}{c}0.34 \\
\pm 0.35 \\
\end{array}$ & $\begin{array}{c}0.42 \\
\pm 0.31 \\
\end{array}$ & $\begin{array}{c}0.89 \\
\pm 0.78 \\
\end{array}$ & $\begin{array}{c}0.85 \\
\pm 0.59 \\
\end{array}$ & $\begin{array}{c}0.38 \\
\pm 0.27 \\
\end{array}$ & $\begin{array}{c}0.60 \\
\pm 0.51 \\
\end{array}$ & $\begin{array}{c}0.28 \\
\pm 0.18 \\
\end{array}$ & $\begin{array}{c}0.77 \\
\pm 0.56 \\
\end{array}$ & $\begin{array}{r}0.79 \\
\mathbf{0} 0.55 \\
\end{array}$ \\
\hline
\end{tabular}

[For daily variations, prevailing WD and other details see supplementary Table S-2a,b,c] 
Table 2: Diagnostic ratio of various PAHs at Menen

\begin{tabular}{|c|c|c|c|c|c|c|c|c|}
\hline \multirow[b]{2}{*}{ Months } & \multicolumn{8}{|c|}{ Diagnostic ratios } \\
\hline & 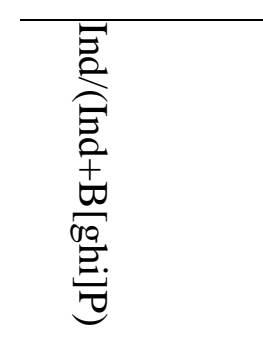 & 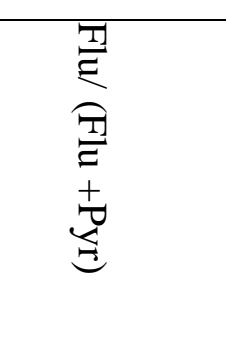 & 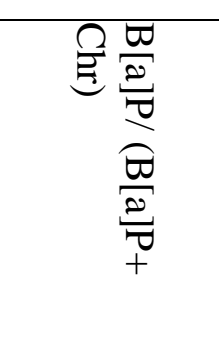 & $\begin{array}{l}D \\
D \\
D \\
D \\
+ \\
D \\
D\end{array}$ & $\begin{array}{l}\frac{\sigma}{\sigma} \\
\frac{\sigma}{\pi} \\
\frac{\pi}{\pi} \\
\frac{\pi}{T}\end{array}$ & $\begin{array}{l}\frac{\sigma}{\tilde{D}} \\
\frac{\sigma}{\sigma} \\
\frac{\sigma a}{\sigma} \\
\frac{\sigma \sigma}{\sigma}\end{array}$ & $\frac{\bar{\Xi}}{\tilde{\sigma}}$ & 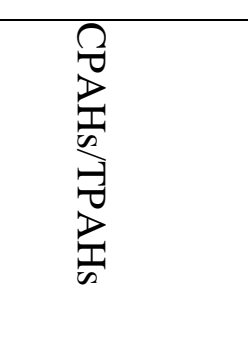 \\
\hline January & $0.47 \pm 0.15$ & $0.13 \pm 0.05$ & $0.35 \pm 0.04$ & $0.82 \pm 0.24$ & $2.26 \pm 0.09$ & $0.81 \pm 0.20$ & $1.00 \pm 0.45$ & $0.88 \pm 0.06$ \\
\hline February & $0.49 \pm 0.05$ & $0.06 \pm 0.07$ & $0.36 \pm 0.04$ & $0.86 \pm 0.06$ & $2.19 \pm 0.09$ & $0.75 \pm 0.17$ & $0.99 \pm 0.20$ & $0.83 \pm 0.05$ \\
\hline March & $0.46 \pm 0.08$ & $0.07 \pm 0.07$ & $0.39 \pm 0.05$ & $0.79 \pm 0.11$ & $2.39 \pm 0.50$ & $0.48 \pm 0.13$ & $0.89 \pm 0.33$ & $0.78 \pm 0.06$ \\
\hline April & $0.59 \pm 0.08$ & $0.19 \pm 0.12$ & $0.39 \pm 0.04$ & $0.87 \pm 0.06$ & $2.49 \pm 0.25$ & $0.82 \pm 0.35$ & $1.52 \pm 0.53$ & $0.81 \pm 0.06$ \\
\hline May & $0.40 \pm 0.17$ & $0.15 \pm 0.06$ & $0.36 \pm 0.07$ & $0.76 \pm 0.14$ & $2.20 \pm 0.11$ & $0.64 \pm 0.47$ & $0.77 \pm 0.41$ & $0.72 \pm 0.07$ \\
\hline June & $0.56 \pm 0.13$ & $0.32 \pm 0.11$ & $0.35 \pm 0.01$ & $0.74 \pm 0.01$ & $2.55 \pm 0.18$ & $0.77 \pm 0.13$ & $1.40 \pm 0.72$ & $0.72 \pm 0.01$ \\
\hline August & $0.59 \pm 0.15$ & $0.22 \pm 0.05$ & $0.35 \pm 0.05$ & $0.92 \pm 0.08$ & $2.44 \pm 0.43$ & $1.35 \pm 0.69$ & $1.66 \pm 0.74$ & $0.64 \pm 0.13$ \\
\hline September & $0.47 \pm 0.08$ & $0.18 \pm 0.08$ & $0.37 \pm 0.04$ & $0.74 \pm 0.09$ & $2.19 \pm 0.11$ & $0.52 \pm 0.12$ & $0.93 \pm 0.24$ & $0.73 \pm 0.05$ \\
\hline October & $0.51 \pm 0.02$ & $0.12 \pm 0.08$ & $0.47 \pm 0.03$ & $0.84 \pm 0.10$ & $2.13 \pm 0.03$ & $0.82 \pm 0.14$ & $1.06 \pm 0.10$ & $0.82 \pm 0.06$ \\
\hline November & $0.58 \pm 0.02$ & $0.08 \pm 0.02$ & $0.42 \pm 0.03$ & $0.53 \pm 0.09$ & $2.30 \pm 0.00$ & $0.80 \pm 0.15$ & $1.37 \pm 0.11$ & $0.88 \pm 0.01$ \\
\hline December & $0.55 \pm 0.09$ & $0.11 \pm 0.06$ & $0.43 \pm 0.07$ & $0.61 \pm 0.16$ & $2.37 \pm 0.28$ & $1.15 \pm 0.58$ & $1.35 \pm 0.60$ & $0.84 \pm 0.06$ \\
\hline Average & $0.52 \pm 0.06$ & $0.15 \pm 0.08$ & $0.38 \pm 0.04$ & $0.77 \pm 0.12$ & $2.32 \pm 0.14$ & $0.81 \pm 0.25$ & $1.18 \pm 0.29$ & $0.79 \pm 0.08$ \\
\hline Source & $\begin{array}{c}\text { Diesel/coal } \\
\text { /wood }\end{array}$ & Gasoline & Diesel & - & Diesel & Traffic & Diesel & Combustion \\
\hline
\end{tabular}


Table 3: Factor analysis of total EPA-PAHs data of Menen.

\begin{tabular}{cccc}
\hline PAH & Factor 1 & Factor 2 & Factor 3 \\
\hline Nap & 0.24 & 0.26 & -0.62 \\
Acpy & 0.46 & 0.69 & 0.37 \\
Acp & -0.04 & 0.41 & 0.68 \\
Flu & 0.57 & 0.08 & -0.28 \\
PA & 0.53 & 0.75 & -0.13 \\
Ant & 0.61 & 0.52 & -0.41 \\
Flut & 0.94 & -0.14 & 0.11 \\
Pyr & 0.78 & 0.46 & 0.06 \\
B[a]A & 0.97 & -0.16 & 0.02 \\
Chr & 0.97 & -0.18 & 0.09 \\
B[b]F & 0.97 & -0.22 & 0.06 \\
B[k]F & 0.97 & -0.21 & 0.05 \\
B[a]P & 0.97 & -0.20 & 0.07 \\
D[ah]A & 0.89 & -0.09 & -0.02 \\
B[ghi]P & 0.98 & -0.15 & 0.05 \\
Ind & 0.97 & -0.19 & 0.02 \\
& & & \\
\hline Eigen value & 10.13 & 2.05 & 1.28 \\
Variance (\%) & 63.3 & 12.8 & 8.01 \\
Cumulative (\%) & 63.3 & 76.1 & 84.1 \\
Origin & Vehicular & Combustion & $?$ \\
\hline
\end{tabular}


Table 4: Criteria used to classify air mass back trajectory atmospheric transport pattern and corresponding average PAHs levels $\left(\mathrm{ng} / \mathrm{m}^{3}\right)$.

\section{Category Description of trajectory categories}

Average PAHs

Levels

\begin{tabular}{|c|c|c|c|}
\hline $\mathrm{BE}$ & $\begin{array}{l}\text { Trajectory stagnating over, or spending most of 4-day } \\
\text { period in the vicinity of the Belgium and Netherlands. }\end{array}$ & 8 & $4.2 \pm 2.6$ \\
\hline AT & $\begin{array}{l}\text { Trajectory spending most of } 4 \text {-day period over the } \\
\text { Atlantic ocean. }\end{array}$ & 8 & $3.7 \pm 3.7$ \\
\hline $\mathrm{AR}$ & $\begin{array}{l}\text { Trajectory spending most of } 4 \text {-day period in the Arctic } \\
\text { region, including those originating in or near } \\
\text { Greenland. }\end{array}$ & 7 & $2.8 \pm 1.7$ \\
\hline UK & $\begin{array}{l}\text { Trajectories originating from or spending most of } 4- \\
\text { days period crossing the United Kingdom. }\end{array}$ & 3 & $3.6 \pm 1.5$ \\
\hline $\mathrm{CE}$ & $\begin{array}{l}\text { The trajectory originating from and spending most of } \\
\text { the time over Central Europe. }\end{array}$ & 4 & $17.5 \pm 15.5$ \\
\hline WE & $\begin{array}{l}\text { Trajectory originating from or spending most of 4-day } \\
\text { period crossing Western Europe. }\end{array}$ & 20 & $9.2 \pm 12.6$ \\
\hline SC & $\begin{array}{l}\text { Trajectory originating from or spending most of } 4 \text {-day } \\
\text { period crossing Scandinavia or Northern Baltic areas. }\end{array}$ & 3 & $6.8 \pm 2.4$ \\
\hline MT & $\begin{array}{l}\text { Trajectory spending most of } 4 \text {-day period crossing } \\
\text { maritime regions close to the Belgium. }\end{array}$ & 5 & $3.7 \pm 3.2$ \\
\hline $\mathrm{EE}$ & $\begin{array}{l}\text { Trajectory originating from or spending most of the 4- } \\
\text { day period crossing Eastern Europe. }\end{array}$ & 2 & $4.2 \pm 0.3$ \\
\hline $\mathrm{UC}$ & $\begin{array}{l}\text { Trajectory unable to be unambiguously classified into } \\
\text { any one trajectory category. }\end{array}$ & 3 & $6.3 \pm 5.2$ \\
\hline
\end{tabular}

